\title{
Effects of zinc oxide nanoparticles on Kupffer cell phagosomal motility, bacterial clearance, and liver function
}

\author{
Christa Y Watson \\ Ramon M Molina \\ Andressa Louzada \\ Kimberly M Murdaugh \\ Thomas C Donaghey \\ Joseph D Brain \\ Center for Nanotechnology \\ and Nanotoxicology, Molecular \\ and Integrative Physiological \\ Sciences Program, Department of \\ Environmental Health, Harvard T.H. \\ Chan School of Public Health, Boston, \\ MA, USA
}

Correspondence: Joseph D Brain Harvard T.H. Chan School of Public Health, 665 Huntington Avenue, Boston, MA 02II5, USA

Tel +l 6174321272

Email brain@hsph.harvard.edu
This article was published in the following Dove Press journal:

International Journal of Nanomedicine

26 June 2015

Number of times this article has been viewed

Background: Zinc oxide engineered nanoparticles ( $\mathrm{ZnO}$ ENPs) have potential as nanomedicines due to their inherent properties. Studies have described their pulmonary impact, but less is known about the consequences of ZnO ENP interactions with the liver. This study was designed to describe the effects of $\mathrm{ZnO}$ ENPs on the liver and Kupffer cells after intravenous (IV) administration.

Materials and methods: First, pharmacokinetic studies were conducted to determine the tissue distribution of neutron-activated ${ }^{65} \mathrm{ZnO}$ ENPs post-IV injection in Wistar Han rats. Then, a noninvasive in vivo method to assess Kupffer cell phagosomal motility was employed using ferromagnetic iron particles and magnetometry. We also examined whether prior IV injection of ZnO ENPs altered Kupffer cell bactericidal activity on circulating Pseudomonas aeruginosa. Serum and liver tissues were collected to assess liver-injury biomarkers and histological changes, respectively.

Results: We found that the liver was the major site of initial uptake of ${ }^{65} \mathrm{ZnO}$ ENPs. There was a time-dependent decrease in tissue levels of ${ }^{65} \mathrm{Zn}$ in all organs examined, reflecting particle dissolution. In vivo magnetometry showed a time-dependent and transient reduction in Kupffer cell phagosomal motility. Animals challenged with $P$. aeruginosa 24 hours post-ZnO ENP injection showed an initial (30 minutes) delay in vascular bacterial clearance. However, by 4 hours, IV-injected bacteria were cleared from the blood, liver, spleen, lungs, and kidneys. Seven days post-ZnO ENP injection, creatine phosphokinase and aspartate aminotransferase levels in serum were significantly increased. Histological evidence of hepatocyte damage and marginated neutrophils were observed in the liver.

Conclusion: Administration of ZnO ENPs transiently inhibited Kupffer cell phagosomal motility and later induced hepatocyte injury, but did not alter bacterial clearance from the blood or killing in the liver, spleen, lungs, or kidneys. Our data show that diminished Kupffer cell organelle motion correlated with $\mathrm{ZnO}$ ENP-induced liver injury.

Keywords: magnetometry, engineered nanoparticles, liver, Kupffer cells, zinc oxide

\section{Introduction}

The potential of nanomedicine has fueled the design and deployment of novel engineered nanoparticles (ENPs) for many biomedical applications. ENPs have high surface area-to-volume ratios and many characteristics providing selected electrical, magnetic, and structural properties that may prove useful in the diagnosis and treatment of diseases. Currently, various metal oxide ENPs are being explored as vehicles for cancer treatments, ${ }^{1}$ tumor detection, ${ }^{2}$ and gene-delivery therapies. ${ }^{3}$ The size, shape, and surface characteristics of metal oxide ENPs can be modified to enable complex interactions with biomolecules, increasing their ability to traverse cellular membranes 
via nonendocytic mechanisms. ${ }^{4}$ Therefore, when tailored correctly, the biological responses to ENPs could lead to enhanced interaction with target cells and tissues in comparison to conventional medicines.

Of particular interest in nanomedicine is $\mathrm{ZnO}$ ENPs. Various studies have reported the selectivity and toxicity of $\mathrm{ZnO}$ ENPs for cancer cells, ${ }^{5,6}$ which may prove useful in cancer treatments. However, the therapeutic use of $\mathrm{ZnO}$ ENPs may alter host immune defenses having beneficial or possibly deleterious effects. For example, ZnO ENPs have been shown to upregulate metallothionein, ${ }^{7}$ an important protein involved in phagocytosis, antigen presentation by macrophages, ${ }^{8}$ and inflammatory responses. ${ }^{9}$ In contrast, $\mathrm{ZnO}$ ENPs also have the potential to reduce the viability of certain immune cells, including macrophages, ${ }^{10}$ and to impair macrophage activity by downregulating the genes coding for major histocompatibility complex class II molecules. ${ }^{11}$ Therefore, it is important to understand the influence of $\mathrm{ZnO}$ ENPs on immune cells to evaluate the potential of these nanoparticles to affect immunological responses.

Although the mechanism of action of ZnO ENPs is not completely understood, it is postulated that increased cytosolic $\mathrm{Zn}^{2+}$ and the generation of reactive oxygen species (ROS) play important roles. ${ }^{12}$ The associated cytotoxicity from these mechanisms is thought to be selective for cells that produce greater levels of ROS or are dividing rapidly, such as immune cells, ${ }^{5}$ bacteria, ${ }^{13}$ and cancer cells. ${ }^{6}$ A prime example of immune cells potentially susceptible to ENP-mediated alterations is Kupffer cells. Kupffer cells are macrophages that line the hepatic sinusoids, and represent the largest population of fixed macrophages within the body. ${ }^{14}$ Their primary purpose is continuously to clear the portal blood of toxins, bacteria, macromolecular debris, and particles. As they perform their biological functions, activation often occurs. However, chronic excessive activation of Kupffer cells has been implicated in the pathogenesis of liver diseases, such as hepatitis and fibrosis. ${ }^{15}$

In previous studies, we utilized ferromagnetic particles and in vivo magnetometry to monitor the motility of particlecontaining phagosomes in Kupffer cells during sepsis or toxic injury. ${ }^{16}$ This noninvasive technique can be used to repeatedly study the intracellular (phagosomal) movement within macrophages. It is an established method to assess cytoskeletal function within lung ${ }^{17-21}$ and liver macrophages in intact animals. ${ }^{19,22,23}$ When injected intravenously (IV), ferromagnetic iron oxide particles are rapidly cleared from the circulation, and the majority of them are retained in macrophages that have access to the circulation, such as in the liver and spleen. ${ }^{24}$ An external magnet is then applied over the organ of interest. This magnetizes the particles within the macrophages by orienting magnetic domains, thus producing a measurable remanent magnetic field (RMF) after removal of the external magnet. This RMF can be monitored using a fluxgate magnetometer. The RMF decays over time, due to the progressive rotation or misalignment of magnetized particle-containing phagosomes and phagolysosomes. ${ }^{25}$ This decrease in the RMF or "relaxation" is the result of phagosomal motion mediated by microtubules, microfilaments, and available adenosine triphosphate. ${ }^{26}$

Modifications in relaxation rates have been reported as a result of toxic exposures; generally, lower relaxation rates indicate decreases in cytoskeleton function and/or toxicity. This technique has been used as an indicator of altered macrophage function after exposure to various toxins, such as cigarette smoke, ${ }^{27}$ malaria infection, ${ }^{16}$ and particles. ${ }^{28}$ In this study, we assessed the effects of IV-injected ZnO ENPs on Kupffer cell phagosomal motility using in vivo magnetometry and on clearance of bacteria from the blood and subsequent killing using bacteriological techniques. Serum biomarkers of liver function were measured to evaluate ENP effects on hepatocytes. In toto, we sought to evaluate the potential consequences of IV-administered ZnO ENPs on liver- and Kupffer cell function.

\section{Materials and methods Particle reagents}

Ferromagnetic $\mathrm{Fe}_{2} \mathrm{O}_{3}$ nanoparticles were obtained from Alfa Aesar (Ward Hill, MA, USA). ZnO ENPs were synthesized in house at the Harvard T.H. Chan School of Public Health Center for Nanotechnology and Nanotoxicology using the versatile engineered nanomaterial-generation system, as previously described..$^{29}$ The primary particle size was determined for $\mathrm{Fe}_{2} \mathrm{O}_{3}$ and $\mathrm{ZnO}$ ENPs using X-ray diffraction. Prior to each experiment, the ENPs were suspended in sterile distilled injectable water at $5 \mathrm{mg} / \mathrm{mL}$. The ENP suspension was sonicated using a protocol previously described. ${ }^{30}$ The ENP suspensions were measured for hydrodynamic diameter $\left(D_{H}\right)$, polydispersity index (PDI), and zeta potential by dynamic light scattering using a Zetasizer Nano ZS (Malvern Instruments, Malvern, UK). Transmission electron microscopy was performed to determine morphology.

\section{Animal handling and ENP exposure}

Eight-week-old Wistar Han rats weighing an average of $0.255 \mathrm{~kg}$ were purchased from Charles River Laboratories (Raleigh, NC, USA). Rats were housed in groups of two in polypropylene cages with food and water provided ad libitum, and were maintained on a 12-hour light/dark cycle. 
All rats were allowed to acclimate for 1 week before each experiment. The protocols used in this study were approved by the Harvard Medical Area Institutional Animal Care and Use Committee. Rats were randomly assigned to one of three different pretreatment groups: vehicle control (sterile injectable $\mathrm{DiH}_{2} \mathrm{O}$ ), suspension of $\mathrm{Fe}_{2} \mathrm{O}_{3}$ only $(\mathrm{n}=6$ rats), or suspension of $\mathrm{ZnO}$ and $\mathrm{Fe}_{2} \mathrm{O}_{3}$ ENPs ( $\mathrm{n}=6$ rats). IV-administered ${ }^{65} \mathrm{ZnO}$ and $\mathrm{Fe}_{2} \mathrm{O}_{3}$ at a ratio of $1: 1(5 \mathrm{mg} / \mathrm{kg}$ each) were injected via the tail vein while rats were anesthetized using $2 \%$ isoflurane.

\section{Pharmacokinetic studies}

To determine the anatomic distribution of injected $\mathrm{ZnO}$ ENPs when combined with $\mathrm{Fe}_{2} \mathrm{O}_{3}$, we performed a pharmacokinetic study using neutron-activated $\mathrm{ZnO}$ ENPs. The $\mathrm{ZnO}$ ENPs were irradiated at the Massachusetts Institute of Technology Nuclear Reactor Laboratory (Cambridge, MA, USA) with thermal neutron flux of $5 \times 10^{13} \mathrm{n} /(\mathrm{cm} \cdot \mathrm{s})$ for 120 hours. Neutron irradiation generated ${ }^{65} \mathrm{Zn}$, which decays with a half-life of 244.3 days and emits gamma energies of 345,770 , and $1,115 \mathrm{keV}$. The resulting specific activity for ${ }^{65} \mathrm{Zn}$ was $41.7 \pm 7.2 \mathrm{kBq} / \mathrm{mg}$ of ${ }^{65} \mathrm{ZnO}$ ENPs. These radioactive particles were used to determine the distribution of IV-injected $\mathrm{ZnO}$ ENPs. ${ }^{65} \mathrm{ZnO}$ and $\mathrm{Fe}_{2} \mathrm{O}_{3}$ at a ratio of $1: 1$ $(5 \mathrm{mg} / \mathrm{kg}$ each) were injected via the tail vein. At 30 minutes, 24 hours, 7 days, and 21 days post-IV injection, groups of three rats/group were killed, and tissue ${ }^{65} \mathrm{Zn}$ levels were analyzed. The whole brain, spleen, kidneys, heart, liver, lungs, gastrointestinal tract, and testes, as well as samples of blood, bone marrow, skeletal muscle, and skin, were collected and weighed. Radioactivity was measured in a Wizard 1480 gamma counter (PerkinElmer Inc, Waltham, MA, USA). Disintegrations per minute were calculated from the net counts per minute and the measured counter efficiency. Data are expressed as a percentage of the administered dose retained in each organ. The radioactivity in organs and tissues not measured in their entirety was estimated from measured aliquots as a percentage of total body weight, as follows: skeletal muscle, $40 \%$; bone marrow, 3.2\%; peripheral blood, 7\%; skin, 19\%; and bone, 6\%. . $^{31,32}$

\section{Magnetometry measurements}

During magnetic relaxation measurements, each rat was anesthetized with an intraperitoneal injection of a mixture of ketamine $(100 \mathrm{mg} / \mathrm{kg})$, xylazine $(10 \mathrm{mg} / \mathrm{kg})$, and acepromazine $(3 \mathrm{mg} / \mathrm{kg})$. The rat was then secured on a Plexiglass platform, and a permanent magnet $(0.43$ Tesla, $2 \times 2 \times 0.5 \mathrm{~cm})$ was placed on the marked area over the liver (xiphoid process) for 2 minutes and then removed. The magnetized rat was immediately placed under a fluxgate magnetometer in gradiometer mode (F 1.067; Foerster Instruments, Pittsburgh, PA, USA), which detects the RMF emanating from the aligned magnetic particles in the liver. The magnetometer is enclosed in a cylindrical Moly permalloy shield to reduce external magnetic noise. The RMF was followed for 30 minutes. WinDaq software (DATAQ Instruments, Akron, $\mathrm{OH}, \mathrm{USA}$ ) was used to collect the data. Since the peak initial field strength $\left(\mathrm{B}_{0}\right)$ cannot be measured directly, due to an approximate 5 - to 10 -second delay needed to move the rat from the magnetizing field into the shielded magnetometer probe, the $\mathrm{B}_{0}$ was estimated by nonlinear regression analyses using GraphPad Prism version 5 (GraphPad Software Inc, La Jolla, CA, USA). Data are presented as a percentage of the extrapolated $\mathrm{B}_{0}$ over time.

\section{Bacterial preparation and administration}

Rats were randomly assigned to one of three different pretreatment groups: 1) control (IV injection of sterile Dulbecco's phosphate-buffered saline, $\mathrm{n}=17$ rats), 2) suspension of $\mathrm{ZnO}$ and $\mathrm{Fe}_{2} \mathrm{O}_{3}$ ENPs ( $\mathrm{n}=5$ rats), or 3 ) suspension of $\mathrm{ZnO}$ ENPs only ( $\mathrm{n}=10$ rats). Twenty-four hours after the injection of $\mathrm{ZnO}, \mathrm{ZnO}$ and $\mathrm{Fe}_{2} \mathrm{O}_{3}$ ENPs together, or saline, we IV-injected each rat with $3.33 \mathrm{~mL} / \mathrm{kg}\left(2 \times 10^{9} \mathrm{cfu} / \mathrm{kg}\right)$ of the final bacterial suspension. The IV route was chosen because it is a common method of administration for both antimicrobial and anticancer drugs. Pseudomonas aeruginosa is one of the most common nosocomial causes of Gram-negative infections and bacteremia, ${ }^{33}$ and thus it is especially relevant to patients with septicemia or undergoing IV therapies. To prepare the bacterial suspension for IV injection, an aliquot of a stock of $P$. aeruginosa was added to tubes containing tryptic soy broth. The resulting suspension was placed in a shaking incubator at $37^{\circ} \mathrm{C}$. After 18 hours of incubation, the suspension was washed and cleared in successive centrifugations and resuspended in sterile Dulbecco's phosphate-buffered saline. After three washes, the final suspension volume was adjusted to an optical density of 1.3 at $600 \mathrm{~nm}$.

\section{Blood and tissue-sample collection and bacteriological analysis}

We randomly assigned rats from each group to be killed at either 10 minutes or 240 minutes after injection of bacteria. Rats scheduled for death at 10 minutes postinjection had sequential blood samples collected at 1, 5, and 10 minutes postinjection. Rats killed at 240 minutes postinjection had sequential blood samples collected at 10, 15, 30, 60, and 240 minutes postinjection. Blood samples were added to previously weighed sterile Eppendorf tubes with $900 \mu \mathrm{L}$ of 
sterile distilled water and their weights recorded. Tenfold serial dilutions in sterile distilled water of each blood sample were prepared. Anesthetized rats were killed by exsanguination, and the liver, lungs, kidneys, and spleen were aseptically removed and weighed. The liver and the spleen were included as they are the primary sites of uptake for circulating bacteria and $\mathrm{ZnO}$ ENPs. Tissue aliquots were weighed and homogenized in sterile distilled water using tissue grinders. After homogenization, tenfold serial dilutions in sterile distilled water of each tissue aliquot were made. The dilutions for each blood and tissue sample were pour-plated in melted trypticase soy agar and incubated for 24 hours.

\section{Liver-injury enzyme assays}

A separate cohort of Wistar Han rats was IV-injected with $5(\mathrm{n}=4), 10(\mathrm{n}=4)$, and $20 \mathrm{mg} / \mathrm{kg}(\mathrm{n}=3) \mathrm{ZnO}$ ENPs. Whole blood was collected in BD (Franklin Lakes, NJ, USA) Vacutainer SST tubes at 24 hours and 7 days postinjection. Samples were centrifuged, and the serum was collected and stored at $-80^{\circ} \mathrm{C}$ until shipment to IDEXX Laboratories (Westbrook, ME, USA) for protein assays reflecting hepatic function. The following enzymes were measured: ALT, ALP, AST, CPK, GGT, total protein, total bilirubin, and albumin.

\section{Statistical analysis}

Differences among treatment groups were analyzed by oneway analysis of variance and Bonferroni multiple-comparison post hoc tests (GraphPad Prism 5). Magnetometry data, such as $\mathrm{B}_{30} / \mathrm{B}_{0}$, were analyzed using Student's $t$-test.

\section{Results}

\section{Nanoparticle characterization}

$\mathrm{ZnO}$ ENPs and iron oxide were characterized to determine surface charge, as well as primary particle and agglomerate size, prior to IV injections. The crystallite primary particle size of $\mathrm{ZnO}$ determined by X-ray diffraction was $20 \pm 3 \mathrm{~nm}$. After dispersion in distilled water and sonication at $242 \mathrm{~J} / \mathrm{mL}$, we observed a mean agglomerate $\mathrm{D}_{\mathrm{H}}$ of $217 \pm 22.9 \mathrm{~nm}$, PDI of 0.224 , and zeta potential of $19.1 \pm 2.2 \mathrm{mV}$ for $\mathrm{ZnO}$ ENPs. $\mathrm{Fe}_{2} \mathrm{O}_{3}$ ENPs had a primary particle size of $19.6 \pm 2.9 \mathrm{~nm}$, and when dispersed and sonicated in sterile water had a $\mathrm{D}_{\mathrm{H}}$ of $163.1 \pm 49.0 \mathrm{~nm}$, PDI of 0.257 , and zeta potential of $-28 \pm 0.3 \mathrm{mV}$. To ensure that the tracer particle $\mathrm{Fe}_{2} \mathrm{O}_{3}$ and $\mathrm{ZnO}$ ENP had the same uptake pattern by hepatic and splenic macrophages, they were mixed together at a ratio of $1: 1$. The combined suspensions had a $\mathrm{D}_{\mathrm{H}}$ of $518.9 \pm 36.5 \mathrm{~nm}$, PDI of 0.606 , and zeta potential of $3.31 \pm 0.5 \mathrm{mV}$. The interval between sonication of ENPs and rat injection was 1-2 minutes.
Therefore, these agglomerate $\mathrm{D}_{\mathrm{H}} \mathrm{s}$ were representative of what was injected IV. Transmission electron microscopy revealed the hexagonal and rod-shaped structure of $\mathrm{Fe}_{2} \mathrm{O}_{3}$ (Figure 1A) and $\mathrm{ZnO}$ ENPs (Figure 1B), respectively. Figure $1 \mathrm{C}-\mathrm{E}$ displays the size distribution of $\mathrm{Fe}_{2} \mathrm{O}_{3}, \mathrm{ZnO}$, and combined suspension of $\mathrm{Fe}_{2} \mathrm{O}_{3}$ and $\mathrm{ZnO}$, respectively.

\section{Distribution of injected ZnO ENPs - pharmacokinetic analysis}

The amounts of total recovered ${ }^{65} \mathrm{Zn}$ in rats over time are shown in Figure 2A. This shows that $82.7 \%$ of the injected dose was recovered at 30 minutes postinjection and declined to $38 \%$ over 7 days. After 21 days, the amount of ${ }^{65} \mathrm{Zn}$ was $25 \%$ in the total rat carcass. Excretion of ${ }^{65} \mathrm{Zn}$ through urine and feces is presented in Figure 2B. At 24 hours postinjection of ${ }^{65} \mathrm{Zn}, 2.1 \%$ had been excreted in the urine and $10.5 \%$ in the feces. Cumulative urine and fecal elimination of ${ }^{65} \mathrm{Zn}$ at 21 days was $4 \%$ and $47 \%$, respectively. The liver was found to have the highest retention of ${ }^{65} \mathrm{Zn}$ at 30 minutes (Figure 2C), which declined to $11 \%$ over a 24-hour period. After 7 days, the presence of $\mathrm{ZnO}$ ENPs in the liver diminished to $3.3 \%$, and only $1.2 \%$ remained after 21 days. Figure 2D displays the overall tissue distribution of ${ }^{65} \mathrm{Zn}$ at four different time points after injection of combined ${ }^{65} \mathrm{ZnO}$ and $\mathrm{Fe}_{2} \mathrm{O}_{3}$. At 24 hours, we observed that ${ }^{65} \mathrm{Zn}$ was found in the bone (14\%), skin (9\%), lungs (13\%), blood (15\%), and plasma (13\%). Retained ${ }^{65} \mathrm{Zn}$ decreased over time from the liver and other organs, most likely due to $\mathrm{ZnO}$ ENP dissolution and clearance of $\mathrm{Zn}$ through the urine and feces. However, notable accumulation of ${ }^{65} \mathrm{Zn}$ within the bone was observed (Figure 2D).

\section{Organelle motility in Kupffer cells after $\mathrm{ZnO}$ nanoparticle exposure}

In vivo magnetometry was employed to assess the impact of ENP exposure on the phagosomal motility of liver macrophages or Kupffer cells. Magnetometric analyses were performed at three time points: 30 minutes, 24 hours, and 7 days. As shown in Figure 3A, 30 minutes after injecting $\mathrm{ZnO}$ ENPs, significant slowing in relaxation was observed compared with control $\left(\mathrm{Fe}_{2} \mathrm{O}_{3}\right.$ only). The slowed relaxation persisted at 24 hours (Figure 3B). However, the motility of particle-containing phagosomes in Kupffer cells returned to the control level at 7 days (Figure 3C).

\section{Effects of $\mathrm{ZnO}$ ENPs on bacterial clearance and killing}

To assess if the observed reduced organelle motility could impact vascular clearance of bacteria from the blood or 

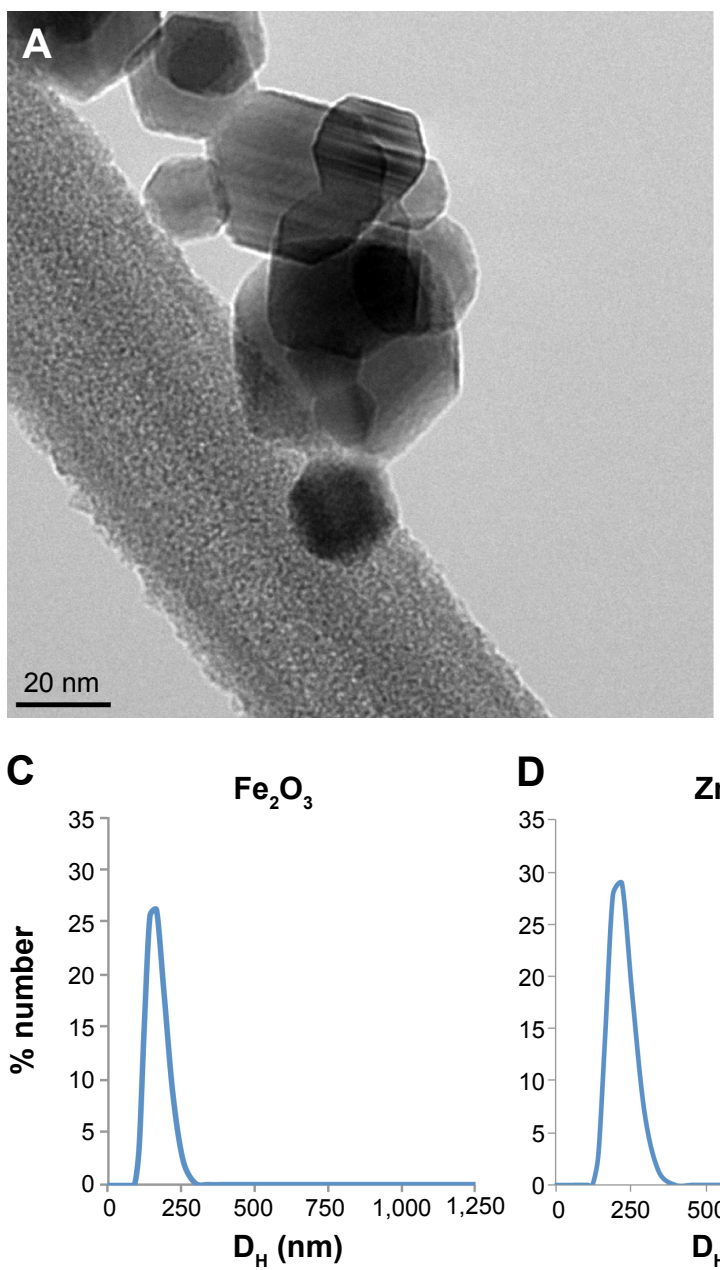

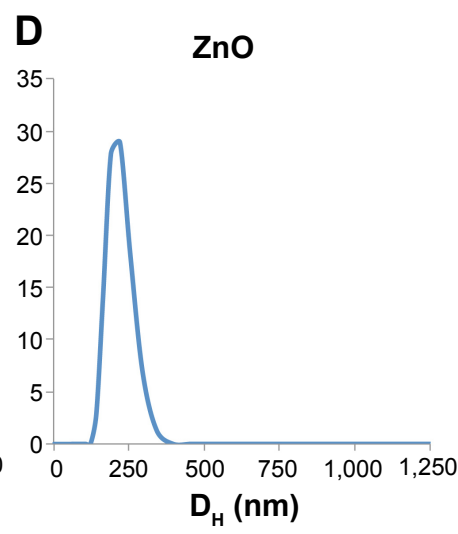

Figure I Electron micrographs and hydrodynamic diameter $\left(D_{H}\right)$ distributions.

Notes: Electron micrographs of ferromagnetic $\mathrm{Fe}_{2} \mathrm{O}_{3}(\mathbf{A})$ and $\mathrm{ZnO}$ nanoparticles $(\mathbf{B})$. $\mathrm{D}_{\mathrm{H}}$ distributions of $(\mathbf{C}) \mathrm{Fe}_{2} \mathrm{O}_{3},(\mathbf{D}) \mathrm{ZnO}$ and $(\mathbf{E}) \mathrm{Fe}_{2} \mathrm{O}_{3}$ and $\mathrm{ZnO}$.

subsequent killing, we injected a separate cohort of Wistar Han rats with $P$. aeruginosa $\left(2 \times 10^{9} \mathrm{cfu} / \mathrm{kg}\right)$. Each rat had received normal saline, $\mathrm{ZnO}$ ENPs, or $\mathrm{ZnO}$ and $\mathrm{Fe}_{2} \mathrm{O}_{3}$ 24 hours earlier. Rats were weighed prior to the pretreatment with ENPs or saline (day 1) and prior to the injection of $P$. aeruginosa (day 2). The original weights (day 1) among all rats were similar. The mean body weight of the rats at day 1 from the control group was $272.7 \pm 5 \mathrm{~g}$, from the group treated with $\mathrm{ZnO}$ ENPs $271.2 \pm 3.6 \mathrm{~g}$, and from the group treated with $\mathrm{ZnO}$ and $\mathrm{Fe}_{2} \mathrm{O}_{3}$ ENPs $267.7 \pm 2.6 \mathrm{~g}$. On day 2, we observed an increase in weight in the control group. In contrast, the rats treated with $\mathrm{ZnO}$ ENPs alone and in combination with $\mathrm{Fe}_{2} \mathrm{O}_{3}$ showed a slight decrease in average body weight (data not shown).

As shown in Figure 4A, there had been rapid clearance of bacteria from the blood at 1 hour postinjection. Although there were initially higher levels of bacteria remaining in the blood of the $\mathrm{ZnO}$ and $\mathrm{ZnO} / \mathrm{Fe}_{2} \mathrm{O}_{3}$ groups, viable bacteria were almost completely cleared from the blood in the first hour in
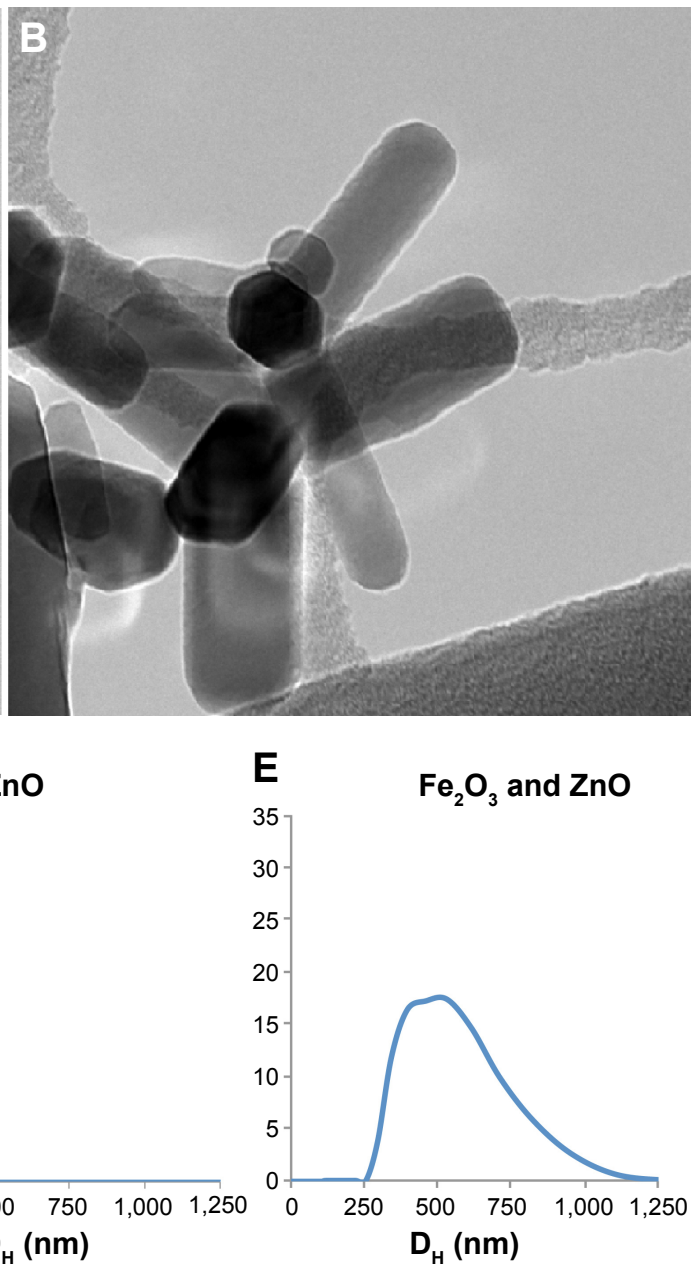

all three groups. The percentages of viable bacteria recovered in the liver, spleen, lungs, kidneys, and blood at 10 minutes postinjection are shown in Figure 4B. After 4 hours, the viable bacteria remaining in the liver, spleen, lungs, kidneys, and blood were significantly reduced, as shown in Figure 4C. A summary of the percentage bacterial killing within each tissue is presented in Figure 4D. The graph indicates that bacteria in the lungs and kidneys were inactivated by almost $100 \%$ over a 4-hour period. Bacterial killing in the liver and spleen was over $92 \%$.

\section{ZnO ENP exposure increases liver-injury enzymes and causes histological changes}

Two of eight liver-injury enzyme biomarkers that were measured showed time-dependent changes (Figure 5). We observed a significant elevation in AST (Figure 5A) at the 5 and $10 \mathrm{mg} / \mathrm{kg}$ doses after 7 days. The higher dose of $20 \mathrm{mg} / \mathrm{kg}$ incited a fivefold increase in AST after 24 hours, which decreased after 7 days. CPK levels at 5, 10, and 

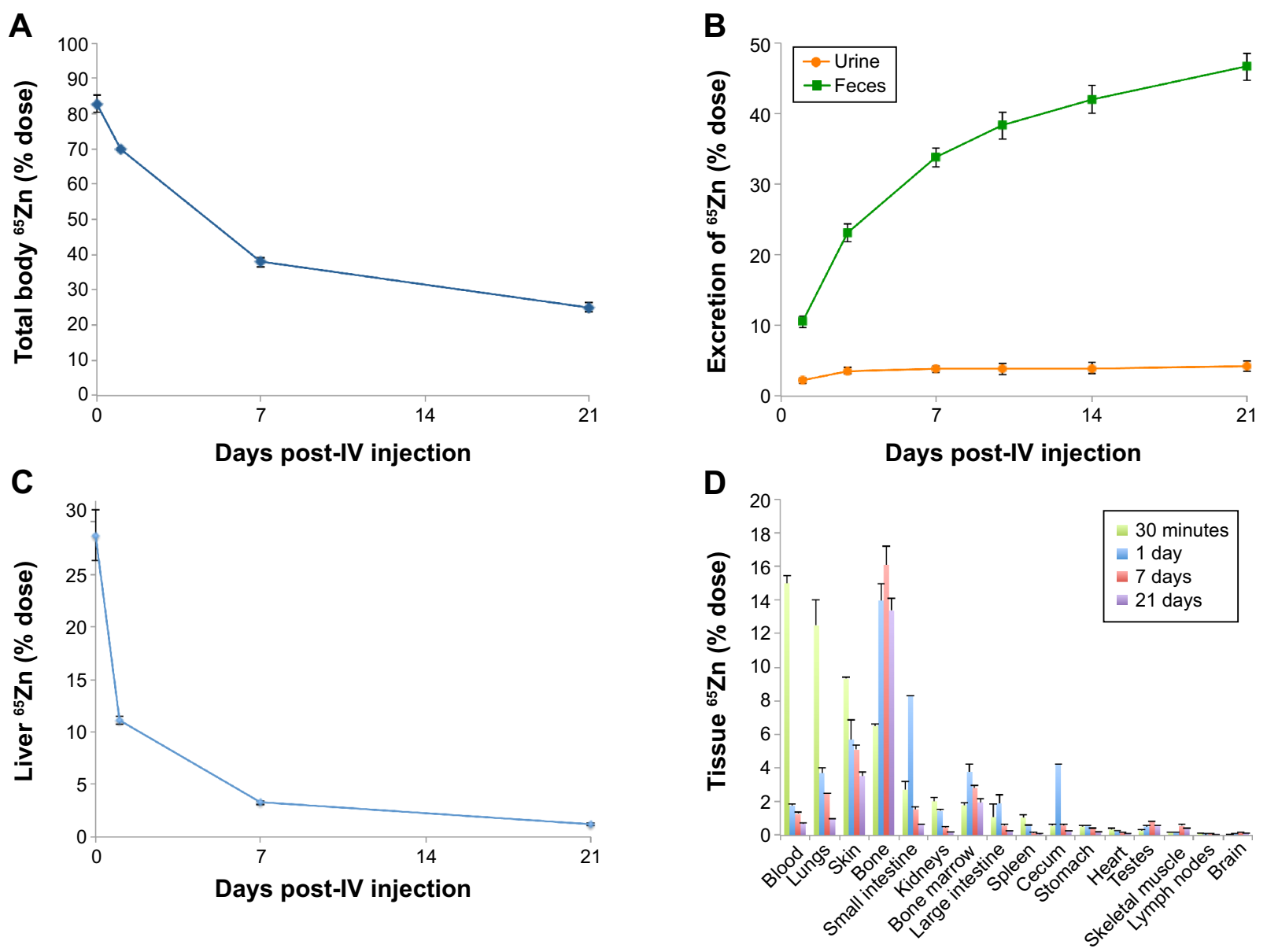

Figure 2 Pharmacokinetics of ${ }^{65} \mathrm{Zn}$ post-intravenous (IV) injection of ${ }^{65} \mathrm{ZnO}$.

Notes: (A) Total distribution of recovered ${ }^{65} \mathrm{Zn}$ in rat tissues at $0,7,14$, and 21 days postinjection. (B) Excretion of ${ }^{65} \mathrm{Zn}$ post-IV injection of ${ }^{65} \mathrm{Zn}$ ENPs. (C) Percentage of injected ${ }^{65} \mathrm{Zn}$ dose retained in the liver diminished over time. (D) Overall organ distribution of ${ }^{65} \mathrm{Zn}$ over time post-IV injection of ${ }^{65} \mathrm{ZnO}$ ENPs.

Abbreviation: ENPs, engineered nanoparticles.

$20 \mathrm{mg} / \mathrm{kg}$ were significantly increased at 7 days (Figure 5B). This elevation coincided with dose-dependent histopathological changes, including necrosis and infiltration of inflammatory cells (Figure 6). Normal liver-tissue structure could be seen in control (saline-administered) rats (Figure 6A). Light micrographs of representative rat liver sections taken at 24 hours post-ENP exposure of $5 \mathrm{mg} / \mathrm{kg}$ show an influx of inflammatory cells (Figure 6B). After 1 week, noticeable areas of hepatocyte granulation and nuclear condensation were evident, along with spotty necrosis (Figure 6C). In Figure 6D, the higher dose of $10 \mathrm{mg} / \mathrm{kg}$ induced a significant influx of neutrophils into the portal triad, which persisted after 7 days (Figure 6E). Figure 6F shows inflammatory cell infiltrate near the hepatic portal triad of a rat injected with $20 \mathrm{mg} / \mathrm{kg}$ of $\mathrm{ZnO}$ ENPs. The inflammation was observed at 7 days, along with focal regions of necrosis and binucleated cells (Figure 6G).

\section{Discussion}

$\mathrm{ZnO}$ ENPs have been associated with various forms of toxicity in biological systems. ${ }^{10,34,35}$ The observed toxicities have been linked to their physicochemical properties, such as dissolution into ionic $\mathrm{Zn}$ and their ability to generate ROS. ${ }^{36}$ Consequently, these same properties have been exploited in the development of nanomedicines. ${ }^{2,37}$ To utilize their potential in nanomedicines fully and avoid adverse health effects, comprehensive toxicological characterization is essential. Traditional in vitro studies are limited in their ability to mimic in vivo systems, which are complex and contain multiple nano-bio interactions that influence biodistribution, clearance, and metabolism, as well as inflammatory and immune responses. Therefore, it is necessary to utilize in vivo studies to confirm in vitro observations. ${ }^{38}$ In this study, we utilized a rat model to assess the effects of IV exposure to ZnO ENPs on Kupffer cell function and on the cells' ability to clear and inactivate circulating $P$. aeruginosa.

To validate that the Kupffer cells were targeted with injected $\mathrm{ZnO}$ in the presence of other ENPs, such as iron oxide, we used neutron-activated $\mathrm{ZnO}$ ENPs to verify the organ localization of administered $\mathrm{ZnO}$ ENPs. The highest percentage of injected ${ }^{65} \mathrm{ZnO}$ ENPs was measured in the liver. 

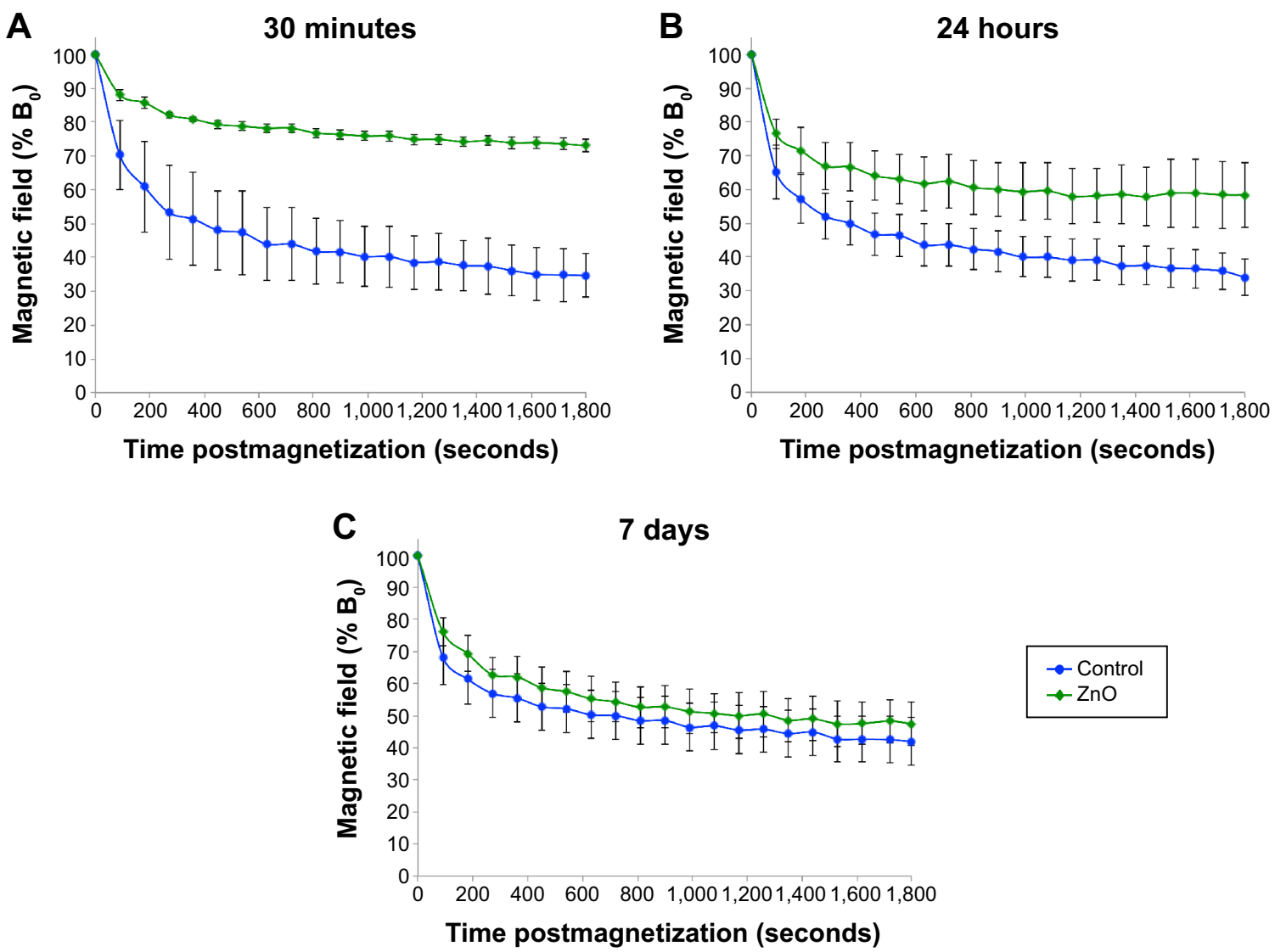

Figure 3 Magnetometric evaluations of Kupffer cells.

Notes: At (A) 30 minutes, (B) 24 hours, and (C) 7 days postinjection of $\mathrm{ZnO}$ engineered nanoparticles. Rats were intravenously injected with $5 \mathrm{mg} / \mathrm{kg}$ each of $\mathrm{ZnO}$ engineered nanoparticles and $\mathrm{Fe}_{2} \mathrm{O}_{3}$ tracer nanoparticles. At each time point, magnetometric measurements were collected for 30 minutes. Significant slowing in relaxation was observed at 30 minutes and 24 hours compared to control animals $\left(\mathrm{Fe}_{2} \mathrm{O}_{3}\right.$ only; Student's $t$-test was used to evaluate the $\left.\mathrm{B}_{30} / \mathrm{B}_{0}\right)$. At 7 days, relaxation returned to normal when there was a $25 \%$ reduction in ${ }^{65} \mathrm{Zn}$ retained in the liver $(\mathrm{n}=6, P<0.0 \mathrm{I})$.

Abbreviation: $\mathrm{B}_{0}$, initial magnetic field strength.

Of the $5 \mathrm{mg} / \mathrm{kg}$ injected, approximately $29 \%$ was taken up by the liver. This was lower than obtained from previous studies in our lab and other studies evaluating IV-administered gold colloids and iron oxide suspension. ${ }^{24}$ However, the particles we used were far smaller, and thus the number injected was far greater at the same dose. It is therefore possible that uptake mechanisms may have been saturated. It is also true that our aggregates had a greater probability of being trapped in or adherent to capillaries in other organs, especially lungs, skin, and bone.

Major goals of this study were to explore whether: 1) $\mathrm{ZnO}$ ENP exposure would reduce organelle motility or 2) reduce the ability of Kupffer cells and other reticuloendothelial system (RES) macrophages to clear $P$. aeruginosa. Using in vivo magnetometry, we observed a transient diminished motility (relaxation) of Kupffer cells due to ZnO ENPs at 30 minutes and 24 hours postexposure. These data correlate with other findings, such as a study that reported a delay in relaxation due to exposure to silicon carbide whiskers in the alveolar macrophages of Syrian golden hamsters. ${ }^{39}$ Some in vitro studies have yielded similar results. For instance, a study of alveolar macrophages recovered from bronchoalveolar lavage fluid from Syrian golden hamsters showed reduced relaxation and toxicity due to cadmium oxide exposures. ${ }^{40} \mathrm{TiO}_{2}$ ENPs, which are extensively used in cosmetics and pharmaceuticals, have also been found to inhibit relaxation and induce membrane damage. ${ }^{41}$ Furthermore, another study showed impairment of cytoskeletal function and early necrotic changes due to in vitro exposure to chrysotile asbestos. ${ }^{42}$ Importantly, cytoskeletal impairment is thought to be the primary mechanism of action that affects relaxation. In previous magnetometric studies, magnetic relaxation was found to be the result of cytoskeletal machinery and ATP ${ }^{43,44}$ Principal components of the cytoskeleton, the actin microfilaments are highly susceptible to oxidative damage and resulting deformations, such as cross-linking, may be enhanced by the presence of $\mathrm{ZnO}$ ENPs or dissolved $\mathrm{Zn}$ ions. ${ }^{45}$ 
A

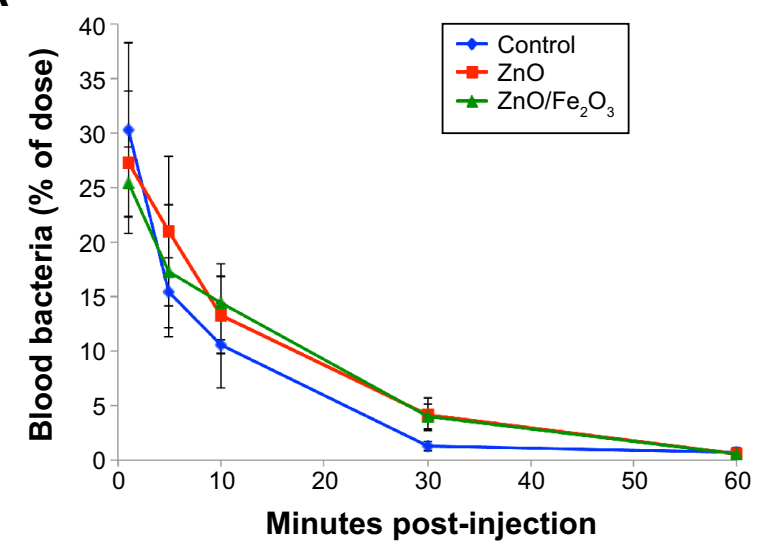

C

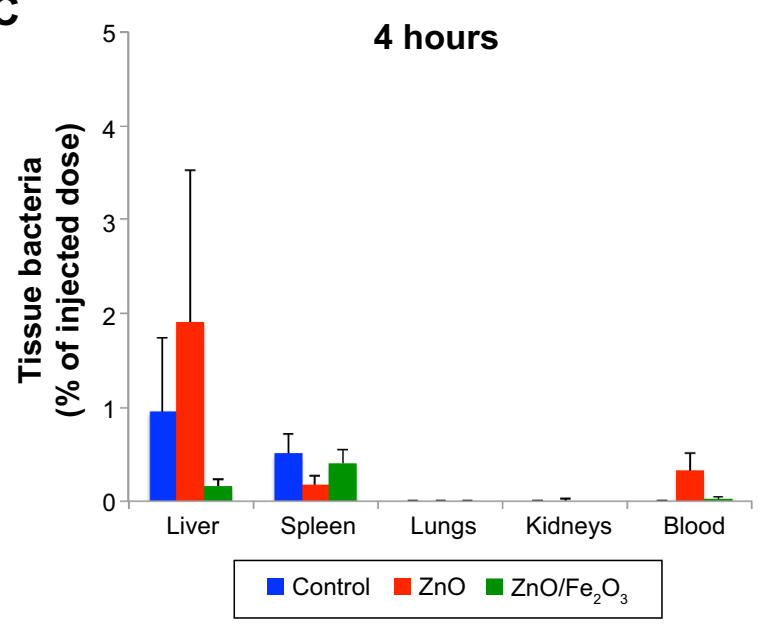

B

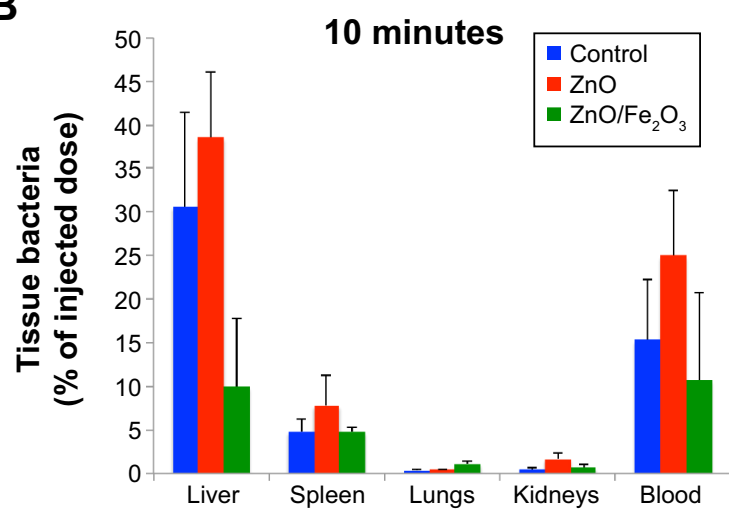

D

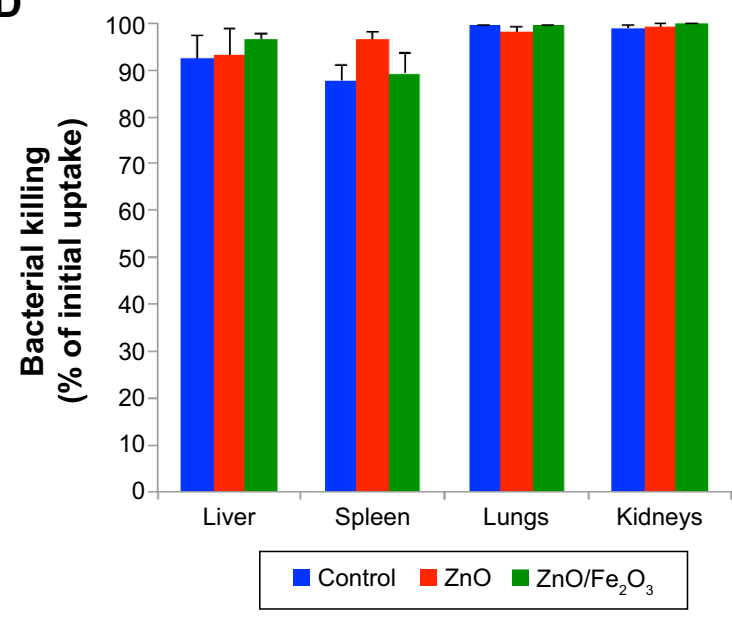

Figure 4 Effect of ZnO ENPs on the fate of IV-injected Pseudomonas aeruginosa.

Notes: (A) Bacterial clearance of Pseudomonas aeruginosa in the blood and tissues. Bacteria were rapidly cleared from the blood. Rats pretreated with $\mathrm{ZnO}$ engineered nanoparticles with or without $\mathrm{Fe}_{2} \mathrm{O}_{3}$ showed slightly slower clearance for the first 30 minutes, but by 60 minutes there were almost no viable bacteria detected in the blood. (B) At 10 minutes postinjection of bacteria, the majority of the injected dose was found in the liver, spleen, and blood. (C) At 4 hours, very low levels of viable bacteria remained in these organs. (D) Bacterial inactivation in 4 hours. Compared to 10 minutes, viable bacteria (cfu/g) in the liver, lungs, and kidneys were significantly decreased. However, pretreatment of rats with $\mathrm{ZnO}$ engineered nanoparticles with or without $\mathrm{Fe}_{2} \mathrm{O}_{3}$ did not affect bacterial killing in these organs.

Abbreviations: ENPs, engineered nanoparticles; IV, intravenous.

A

AST

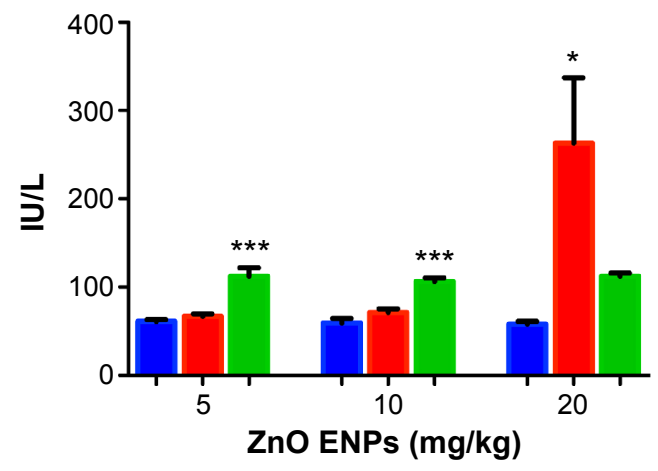

Baseline $\square 24$ hours $\square$ days
B

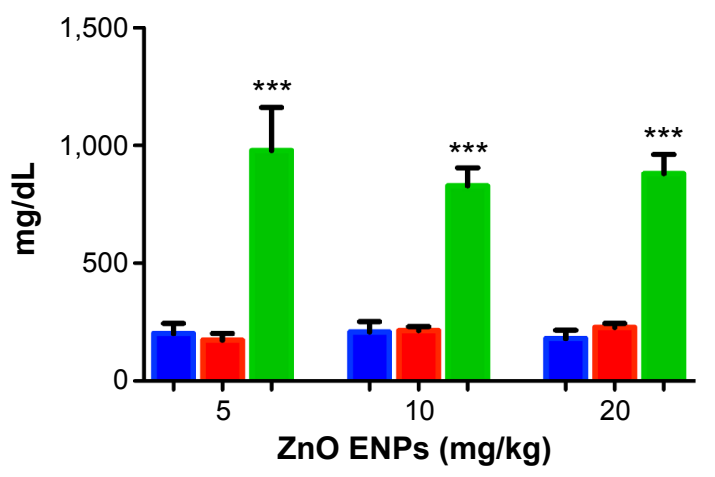

Baseline

7 days

Figure 5 Effect of $\mathrm{ZnO}$ engineered nanoparticles (ENPs) on liver function.

Notes: (A) Time-dependent significant increases in aspartate aminotransferase (AST) were observed in rats after intravenous administration of ZnO ENPs. At the higher dose of $20 \mathrm{mg} / \mathrm{kg}$ ZnO ENPs, a fivefold increase in AST was observed. However, it had decreased by 7 days. (B) Increases in creatine phosphokinase (CPK) were also found 7 days after $\mathrm{ZnO}$ ENP injection. The $P$-values were determined by one-way ANOVA followed by Bonferroni's post-hoc test, where $* P \leq 0.05$, and $* * * P \leq 0.000 \mathrm{I}$ versus baseline. 


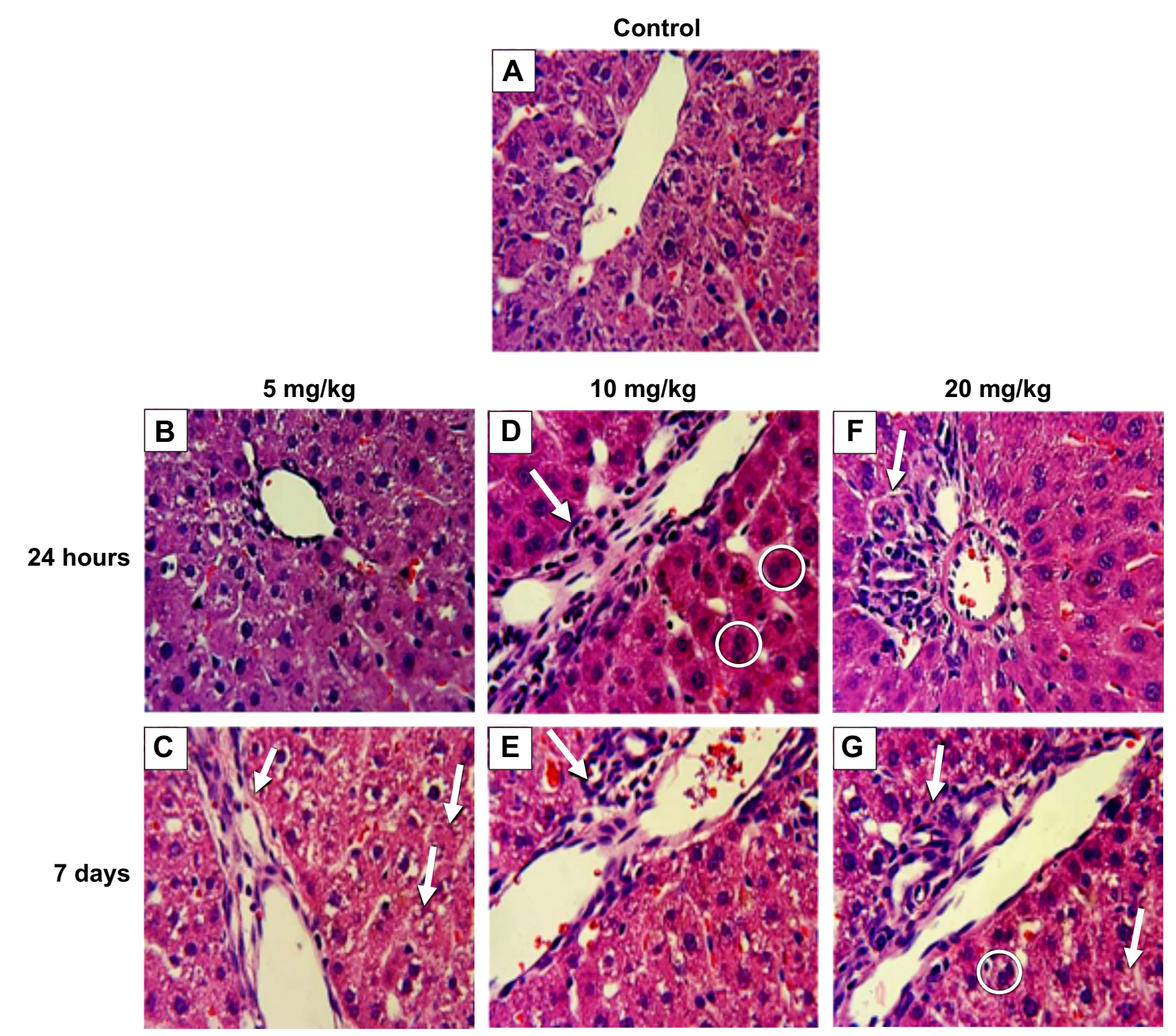

Figure 6 Effect of $\mathrm{ZnO}$ nanoparticles on liver histology of male Wistar Han rats.

Notes: (A) Control (intravenously injected with sterile saline). (B) At 24 hours, hepatocyte swelling was evident with an intravenous dose of $5 \mathrm{mg} / \mathrm{kg}$ of $\mathrm{ZnO}$ engineered nanoparticles (ENPs). (C) After 7 days, granulation and necrotic regions accompanied by neutrophil infiltration were observed; the arrow on the left indicates neutrophil infiltration; the arrows on the right indicate granulation and necrotic regions. (D) At 24 hours, $10 \mathrm{mg} / \mathrm{kg} \mathrm{ZnO} \mathrm{ENPs} \mathrm{caused} \mathrm{an} \mathrm{influx} \mathrm{of} \mathrm{neutrophils} \mathrm{(arrow)} \mathrm{and} \mathrm{binucleated}$ hepatocytes (circled). (E) At 7 days, inflammation and liver necrosis were evident (arrow). (F) At 24 hours, $20 \mathrm{mg} / \mathrm{kg} \mathrm{ZnO} \mathrm{ENPs} \mathrm{induced} \mathrm{inflammatory} \mathrm{cell} \mathrm{infiltration}$ (arrow). (G) At 7 days, inflammatory cell infiltration remained (upper arrow), along with binucleated cells (circled) and some necrosis (lower arrow).

Our data also explored whether IV exposure to ZnO ENPs may impair Kupffer cell phagosomal motion and activity, and in turn may increase the risk of infection following bacteremia. This possibility is suggested by the fact that $\mathrm{ZnO}$ ENPs can generate ROS in different ways. They can indirectly increase ROS generation by saturating oxidative defense compounds, which are then unavailable to bind other transition metal ions, such as $\mathrm{Fe}$ and $\mathrm{Cu}$. These transition metals are then free to catalyze Fenton-type reactions. ${ }^{46,47}$ Moreover, ZnO ENPs can directly generate ROS, because they present a significant number of electron-hole pairs $\left(\mathrm{e}^{-}-\mathrm{h}^{+}\right)$. The electrons and holes can react with the oxygen and hydroxyl ions, respectively, in the ZnO ENPs' surrounding aqueous environment. This produces highly reactive free radical compounds, including the superoxide anion (from electrons) and hydroxyl radicals (from holes). ${ }^{37}$ Importantly, ZnO ENPs are highly soluble, especially when in the acidic compartments of phagolysosomes. This has been shown to cause membrane destabilization, leading to the release of toxic amounts of $\mathrm{Zn}$ within intra- and extracellular environments. ${ }^{48}$ Whether by direct or indirect oxidation, we surmised that $\mathrm{ZnO}$ ENPs might affect the bactericidal activity of Kupffer cells within the liver and other RES macrophages, such as splenic and bone marrow macrophages. However, our data indicate that ZnO ENPs did not impair the ability of RES macrophages to clear and inactivate bacteria. By 4 hours, virtually all injected bacteria were eliminated from the blood, liver, spleen, lung, and kidneys. Our results are consistent with other studies. 
For example, pretreatment with IV injection of crystalline silica was shown not to inhibit the uptake of Salmonella typhimurium in a rat liver-perfusion model. ${ }^{49}$ Additionally, only minor reductions in the clearance of Trypanosoma musculi were observed after silica exposure in mice. ${ }^{50}$

A potential contributing factor in the elimination of bacteria from the blood and tissues is the recruitment of neutrophils during sepsis. This possibility is supported by studies showing that in the early stages of infection, recruited neutrophils contribute to the removal of bacteria along with Kupffer cells. ${ }^{51}$ Although neutrophils comprise only a small portion of the nonparenchymal liver cells in normal murine tissue, Gregory and Wing found that 10 - to 20-fold increases in neutrophils can occur 2 hours after Listeria monocytogenes infection. ${ }^{52}$ In certain instances, the elimination of bacteria from the liver may also be enhanced by the regulatory activity of Kupffer cells over neutrophils, in addition to their own bactericidal activity. ${ }^{52}$ Consistent with this idea, we observed neutrophilia in whole blood samples of rats preexposed to $\mathrm{ZnO}$ ENPs then challenged with $P$. aeruginosa 24 hours later (data not shown). This suggests recruitment of neutrophils from the blood to other organs and possibly the liver. Therefore, impaired Kupffer cells may rely on neutrophil recruitment to help eliminate bacteria. However, neutrophils and other aspects of inflammation might induce liver injury over time.

Of the eight liver-injury enzymes analyzed, AST and CPK were both increased at 7 days after exposure to $\mathrm{ZnO}$ ENPs, suggesting liver injury. The highest dose of $20 \mathrm{mg} / \mathrm{kg}$ induced a fivefold increase in AST after 24 hours. AST is a known serum biomarker of liver injury that is elevated due to hepatocellular injury. ${ }^{53}$ Similarly, in a study investigating the effects of nanoceria on rat liver, AST was significantly elevated in response to IV injections. ${ }^{54}$ It is important to note that the elevation of AST in tandem with CPK could also be related to extrahepatic tissue trauma, such as muscle or heart injury. ${ }^{55}$ Our experimental design and results differed from a study by Wang et al. ${ }^{56} \mathrm{~A}$ principal difference is that we administered our reagents IV, while Wang et al exposed the animals by direct spraying of dry powder into both nasal passages using a dry-powder sprayer. The elevated serum biomarkers found within our work may have differed from this study because of the different route of administration and especially far-higher dose. The authors found severe liver and lung histopathological changes after 3 days of exposure (twice daily) to iron oxide or $\mathrm{ZnO}$ nanomaterials, but no increases in serum biomarkers of the liver. ${ }^{56}$

Histological analysis of liver sections showed areas of necrosis accompanied by significant inflammatory cell infiltration near the hepatic portal triad at day 7 of ENP exposure. By this time, the engulfed $\mathrm{ZnO}$ ENPs would have dissolved, releasing zinc ions, which may have caused toxicity to the surrounding hepatocytes. This "Trojan horse" scenario is consistent with a study investigating the effect of silica ENPs on Kupffer cell-mediated hepatic injury. ${ }^{57}$ The authors found significant histological changes in the liver due to IV administered silica ENPs ( $5 \mathrm{mg} / \mathrm{kg}$ ) to Sprague Dawley rats. They surmised that the significant toxicological and histological changes were induced by Kupffer cell activation, the release of ROS, and inflammation in response to the silica particles. The same study also utilized an in vitro validation study where rat liver cells were exposed to the culture media from Kupffer cells treated with silica ENPs. It was concluded that Kupffer cell metabolites released in response to silica were toxic to hepatocytes. The involvement of Kupffer cells in the pathogenesis of liver injury mediated by chemicals is well documented, ${ }^{58-60}$ and might be important in ENP-mediated liver damage as well.

In summary, the results presented here show that $\mathrm{ZnO}$ ENPs at $5 \mathrm{mg} / \mathrm{kg}$ could alter Kupffer cell phagosomal motility. However, this reduction in phagosomal motility of Kupffer cells did not significantly inhibit the bacterial clearance from the blood or alter the ability of the liver and other organs to kill $P$. aeruginosa. This may have been due in part to possible margination of neutrophils from the blood into the liver and their subsequent participation in bacterial inactivation. Over time, liver intracellular enzymes were elevated, and histological changes were observed at 5,10 , and $20 \mathrm{mg} / \mathrm{kg}$ doses of $\mathrm{ZnO}$ ENPs, which might have been due to released $\mathrm{Zn}$ ions. Interestingly, these toxicological changes in hepatocytes coincided with the restoration of phagosomal motility in Kupffer cells at 7 days. These data indicate the potential of Kupffer cells to mediate liver injury and of the utility of magnetometry as indicators of ENP-mediated liver toxicity.

\section{Conclusion}

We showed that injected ZnO ENPs cause an early and reversible reduction in Kupffer cell phagosomal motion, and later cause hepatocellular injury. However, the capacity of the liver, spleen, lungs, and kidneys to clear and inactivate circulating bacteria were not affected, probably in part due to compensatory mechanisms, such as neutrophil margination in the liver. The release of bioactive metabolites or $\mathrm{Zn}$ ions from Kupffer cells may cause adverse effects on the hepatocytes over time, as indicated by histological evidence of liver inflammation, and by increased serum CPK and AST levels. We conclude that $\mathrm{ZnO}$ ENPs may not significantly reduce the bactericidal capacity of the liver, but can alter 
Kupffer cells and the liver microenvironment, leading to hepatotoxicity over time. These risks must be balanced against the potential benefits, in order to utilize ZnO ENPs as nanomedicines. Nanomedicines utilizing ZnO ENPs will have a range of applications, depending on the desired target, the outcome, and the nature of the formulation. Since almost all medicines have side effects, the key criteria remain efficacy and safety. Continued exploration of potential side effects is warranted.

\section{Acknowledgments}

The authors thank Melissa Curran for her help with edits. Also, special thanks to Phil Demokritou for supplying the ZnO ENPs. The authors acknowledge the financial support from NIH (grant P30ES000002). CYW was funded by an NIH NHLBI Ruth L Kirschstein T32 training grant (NIH HL007118).

\section{Disclosure}

The authors report no conflicts of interest in this work.

\section{References}

1. Brannon-Peppas L, Blanchette JO. Nanoparticle and targeted systems for cancer therapy. Adv Drug Deliv Rev. 2004;56(11):1649-1659.

2. Yang SC, Shen YC, Lu TC, Yang TL, Huang JJ. Tumor detection strategy using ZnO light-emitting nanoprobes. Nanotechnology. 2012;23(5) 055202.

3. Zhang P, Liu W. ZnO QD@PMAA-co-PDMAEMA nonviral vector for plasmid DNA delivery and bioimaging. Biomaterials. 2010;31(11): 3087-3094.

4. Geiser M, Rothen-Rutishauser B, Kapp N, et al. Ultrafine particles cross cellular membranes by nonphagocytic mechanisms in lungs and in cultured cells. Environ Health Perspect. 2005;113(11):1555-1560.

5. Hanley C, Layne J, Punnoose A, et al. Preferential killing of cancer cells and activated human $\mathrm{T}$ cells using $\mathrm{ZnO}$ nanoparticles. Nanotechnology. 2008;19(29):295103.

6. Premanathan M, Karthikeyan K, Jeyasubramanian K, Manivannan G. Selective toxicity of $\mathrm{ZnO}$ nanoparticles toward Gram-positive bacteria and cancer cells by apoptosis through lipid peroxidation. Nanomedicine. 2011;7(2):184-19.

7. Moos PJ, Olszewski K, Honeggar M, et al. Responses of human cells to $\mathrm{ZnO}$ nanoparticles: a gene transcription study. Metallomics. 2011; 3(11):1199-1211.

8. Sugiura T, Kuroda E, Yamashita U. Dysfunction of macrophages in metallothionein-knock out mice. J UOEH. 2004;26(2):193-205.

9. Roy R, Kumar S, Verma AK, et al. Zinc oxide nanoparticles provide an adjuvant effect to ovalbumin via a Th2 response in Balb/c mice. Int Immunol. 2014;26(3):159-172.

10. Wilhelmi V, Fischer U, Weighardt H, et al. Zinc oxide nanoparticles induce necrosis and apoptosis in macrophages in a p47phox- and Nrf2independent manner. PLoS One. 2013;8(6):e65704.

11. Tuomela S, Autio R, Buerki-Thurnherr T, et al. Gene expression profiling of immune-competent human cells exposed to engineered zinc oxide or titanium dioxide nanoparticles. PLoS One. 2013;8(7):e68415.

12. Sahu D, Kannan GM, Vijayaraghavan R, Anand T, Khanum F. Nanosized zinc oxide induces toxicity in human lung cells. ISRN Toxicol. 2013;2013:316075.

13. Kairyte K, Kadys A, Luksiene Z. Antibacterial and antifungal activity of photoactivated $\mathrm{ZnO}$ nanoparticles in suspension. J Photochem Photobiol B. 2013;128:78-84.
14. Thomas P. Kupffer cells. In: Schwab M, editor. Encyclopedia of Cancer. Heidelberg: Springer; 2012:1963-1965.

15. Kolios G, Valatas V, Kouroumalis E. Role of Kupffer cells in the pathogenesis of liver disease. World J Gastroenterol. 2006;12(46): 7413-7420.

16. Bellows CF, Molina RM, Brain JD. Diminished organelle motion in murine Kupffer cells during the erythrocytic stage of malaria. $J R S O c$ Interface. 2011;8(58):711-719.

17. Molina RM, Brain JD. In vivo comparison of cat alveolar and pulmonary intravascular macrophages: phagocytosis, particle clearance, and cytoplasmic motility. Exp Lung Res. 2007;33(2):53-70.

18. Moller W, Barth W, Kohlhäuff M, Häussinger K, Stahlhofen W, Heyder J. Human alveolar long-term clearance of ferromagnetic ironoxide microparticles in healthy and diseased subjects. Exp Lung Res. 2001;27(7):547-568.

19. Weinstock SB, Brain JD. Comparison of particle clearance and macrophage phagosomal motion in liver and lungs of rats. $J$ Appl Physiol (1985). 1988;65(4):1811-1820.

20. Brain JD, Bloom SB, Valberg PA, Gehr P. Correlation between the behavior of magnetic iron oxide particles in the lungs of rabbits and phagocytosis. Exp Lung Res. 1984;6(2):115-131.

21. Brain JD, Godleski J, Kreyling W. In vivo evaluation of chemical biopersistence of nonfibrous inorganic particles. Environ Health Perspect. 1994;102 Suppl 5:119-125.

22. Gehr P, Brain JD, Bloom SB. Noninvasive studies of Kupffer cells in situ by magnetometry. J Leukoc Biol. 1984;35(1):19-30.

23. Gehr P, Brain JD, Bloom SB, Valberg PA. Magnetic particles in the liver: a probe for intracellular movement. Nature. 1983;302(5906): 336-338.

24. Brain JD, Molina RM, DeCamp MM, Warner AE. Pulmonary intravascular macrophages: their contribution to the mononuclear phagocyte system in 13 species. Am J Physiol. 1999;276(1 Pt 1):L146-L154.

25. Valberg PA, Albertini DF. Cytoplasmic motions, rheology, and structure probed by a novel magnetic particle method. J Cell Biol. 1985; 101(1):130-140.

26. Valberg P, Feldman H. Magnetic particle motions within living cells. Measurement of cytoplasmic viscosity and motile activity. Biophys $J$. 1987;52(4):551-561.

27. Brain JD. Macrophage damage in relation to the pathogenesis of lung diseases. Environ Health Perspect. 1980;35:21-28.

28. Moller W, Brown D, Kreyling W, Stone V. Ultrafine particles cause cytoskeletal dysfunctions in macrophages: role of intracellular calcium. Part Fibre Toxicol. 2005;2:7.

29. Demokritou P, Büchel R, Molina RM, Deloid GM, Brain JD, Pratsinis SE. Development and characterization of a versatile engineered nanomaterial generation system (VENGES) suitable for toxicological studies. Inhal Toxicol. 2010;22 Suppl 2:107-116.

30. Cohen J, Deloid G, Pyrgiotakis G, Demokritou P. Interactions of engineered nanomaterials in physiological media and implications for in vitro dosimetry. Nanotoxicology. 2013;7:417-431.

31. Brown RP, Delp MD, Lindstedt SL, Rhomberg LR, Beliles RP. Physiological parameter values for physiologically based pharmacokinetic models. Toxicol Ind Health. 1997;13(4):407-484.

32. Schoeffner DJ, Warren DA, Muralidara S, Bruckner JV, Simmons JE Organ weights and fat volume in rats as a function of strain and age. J Toxicol Environ Health A. 1999;56(7):449-462.

33. Pereira CA, Marra AR, Camargo LF, et al. Nosocomial bloodstream infections in Brazilian pediatric patients: microbiology, epidemiology, and clinical features. PLoS One. 2013;8(7):e68144.

34. Ahamed M, Akhtar MJ, Raja M, et al. ZnO nanorod-induced apoptosis in human alveolar adenocarcinoma cells via p53, survivin and bax/bcl-2 pathways: role of oxidative stress. Nanomedicine. 2011;7(6):904-913.

35. Kao Y, Chen Y, Cheng T, Chiung Y, Liu P. Zinc oxide nanoparticles interfere with zinc ion homeostasis to cause cytotoxicity. Toxicol Sci. 2011;125(2):462-472.

36. Xia T, Zhao Y, Sager T, et al. Decreased dissolution of $\mathrm{ZnO}$ by iron doping yields nanoparticles with reduced toxicity in the rodent lung and zebrafish embryos. ACS Nano. 2011;5(2):1223-1235. 
37. Rasmussen JW, Martinez E, Louka P, Wingett DG. Zinc oxide nanoparticles for selective destruction of tumor cells and potential for drug delivery applications. Expert Opin Drug Deliv. 2010;7(9):1063-1077.

38. Sharma V, Singh P, Pandey A, Dhawan A. Induction of oxidative stress, DNA damage and apoptosis in mouse liver after sub-acute oral exposure to zinc oxide nanoparticles. Mutat Res. 2011;745(1-2):84-91.

39. Watanabe M, Okada M, Aizawa Y, Sakai Y, Yamashina S, Kotani M. Magnetometric evaluation for the effects of silicon carbide whiskers on alveolar macrophages. Ind Health. 2000;38(2):239-245.

40. Niitsuya M, Watanabe M, Okada M, et al. Magnetometric evaluation of cadmium oxide-induced toxicity to pulmonary alveolar macrophages of Syrian golden hamsters. J Toxicol Environ Health A. 2003;66(4):365-378.

41. Watanabe M, Okada M, Kudo Y, et al. Differences in the effects of fibrous and particulate titanium dioxide on alveolar macrophages of Fischer 344 rats. J Toxicol Environ Health A. 2002;65(15):1047-1060.

42. Keira T, Okada M, Katagiri H, Aizawa Y, Okayasu I, Kotani M. Magnetometric evaluation for the effect of chrysotile on alveolar macrophages. Tohoku J Exp Med. 1998;186(2):87-98.

43. Möller W, Takenaka S, Rust M, Stahlhofen W, Heyder J. Probing mechanical properties of living cells by magnetopneumography. J Aerosol Med. 1997;10(3):173-186.

44. Möller W, Nemoto I, Matsuzaki T, Hofer T, Heyder J. Magnetic phagosome motion in J774A. 1 macrophages: influence of cytoskeletal drugs. Biophys J. 2000;79(2):720-730.

45. Möller W, Takenaka S, Buske N, Felten K, Heyder J. Relaxation of ferromagnetic nanoparticles in macrophages: in vitro and in vivo studies. J Magn Magn Mater. 2005;293(1):245-251.

46. Krezel A, Hao Q, Maret W. The zinc/thiolate redox biochemistry of metallothionein and the control of zinc ion fluctuations in cell signaling. Arch Biochem Biophys. 2007;463(2):188-200.

47. Chevion M. A site-specific mechanism for free radical induced biological damage: the essential role of redox-active transition metals. Free Radic Biol Med. 1988;5(1):27-37.

48. Cho WS, Duffin R, Howie SE, et al. Progressive severe lung injury by zinc oxide nanoparticles; the role of $\mathrm{Zn} 2+$ dissolution inside lysosomes. Part Fibre Toxicol. 2011;8:27.
49. Friedman RL, Moon RJ. Role of Kupffer cells, complement, and specific antibody in the bactericidal activities of perfused livers. Infect Immun. 1980;29(1):152-157.

50. Kongshavn PA, Shaw K, Ghadirian E, Ulczak O. Failure to demonstrate a major role for Kupffer cells and radiosensitive leukocytes in immunoglobulin-mediated elimination of Trypanosoma musculi. Infect Immun. 1990;58(6):1971-1978.

51. Gregory SH, Sagnimeni AJ, Wing EJ. Bacteria in the bloodstream are trapped in the liver and killed by immigrating neutrophils. J Immunol. 1996;157(6):2514-2520.

52. Gregory S, Wing E. Neutrophil-Kupffer cell interaction: a critical component of host defenses to systemic bacterial infections. J Leukoc Biol. 2002;72(2):239-248.

53. Alvarez AM, Mukherjee D. Liver abnormalities in cardiac diseases and heart failure. Int J Angiol. 2011;20(3):135-142.

54. Tseng MT, Lu X, Duan X, et al. Alteration of hepatic structure and oxidative stress induced by intravenous nanoceria. Toxicol Appl Pharmacol. 2012;260(2):173-182.

55. Lofthus DM, Stevens SR, Armstrong PW, Granger CB, Mahaffey KW. Pattern of liver enzyme elevations in acute ST-elevation myocardial infarction. Coron Artery Dis. 2012;23(1):22-30.

56. Wang L, Wang L, Ding W, Zhang F. Acute toxicity of ferric oxide and zinc oxide nanoparticles in rats. J Nanosci Nanotechnol. 2010;10(12): 8617-8624.

57. Chen Q, Xue Y, Sun J. Kupffer cell-mediated hepatic injury induced by silica nanoparticles in vitro and in vivo. Int J Nanomedicine. 2013; 8:1129-1140.

58. Roberts RA, Ganey PE, Ju C, Kamendulis LM, Rusyn I, Klaunig JE. Role of the Kupffer cell in mediating hepatic toxicity and carcinogenesis. Toxicol Sci. 2007;96(1):2-15.

59. Ito Y, Bethea NW, Abril ER, McCuskey RS. Early hepatic microvascular injury in response to acetaminophen toxicity. Microcirculation. 2003; 10(5):391-400

60. Steib C, Gerbes A. Signaling pathways in liver diseases Kupffer cells. In: Dufour JF, Clavien PA, editors. Signaling Pathways in Liver Diseases. Heidelberg: Springer; 2010:69-78.
International Journal of Nanomedicine

\section{Publish your work in this journal}

The International Journal of Nanomedicine is an international, peerreviewed journal focusing on the application of nanotechnology in diagnostics, therapeutics, and drug delivery systems throughout the biomedical field. This journal is indexed on PubMed Central, MedLine, CAS, SciSearch ${ }^{\circledR}$, Current Contents ${ }^{\circledR} /$ Clinical Medicine,

\section{Dovepress}

Journal Citation Reports/Science Edition, EMBase, Scopus and the Elsevier Bibliographic databases. The manuscript management system is completely online and includes a very quick and fair peer-review system, which is all easy to use. Visit http://www.dovepress.com/ testimonials.php to read real quotes from published authors. 